\title{
REGIONAL NURSING COUNCIL OF SANTA CATARINA (1975-1986): IMPORTANCE FOR THE PROFESSION
}

\author{
Maria Lígia dos Reis Bellaguardaํ, Maria Itayra Padilha², Denise Elvira Pires de Pires ${ }^{3}$
}

\footnotetext{
${ }^{1}$ Ph.D. in Nursing. Curso de Enferamgem, Centro Universitário Estácio de Santa Catarina. Florianópolis, Santa Catarina, Brazil. E-mail: bellaguardaml@gmail.com

2 Ph.D. in Nursing. Professor, Departamento e Programa de Pós-Graduação em Enfermagem, Universidade Federal de Santa Catarina (UFSC). CNPq researcher. Florianópolis, Santa Catarina, Brazil. E-mail: itayra.padilha@ufsc.br

${ }^{3}$ Ph.D. in Social Sciences. Professor, Departamento e Programa de Pós-Graduação em Enfermagem, UFSC. CNPq researcher. Florianópolis, Santa Catarina, Brazil. E-mail: piresdp@yahoo.com
}

\begin{abstract}
Socio-historical and qualitative study aiming to rescue the establishment process of the Regional Nursing Council of Santa Catarina and characterize its importance to the profession. It presents its theoretical support on the ideas of Eliot Freidson and New History. In the method, oral history and documentary research were used, involving eight nurses who implemented the representative organization in the referred time frame. The principles of Content Analysis guided data analysis, which were organized according to the mandates of the Regional Nursing Council of Santa Catarina from 1975 to 1986. During the implantation of the professional Council, there was a fragile notion about the objectives of the council and a slow supervision process. It is concluded that the importance of the establishment of the profession Council was known by the leaders and little understood by all professionals in the state.
\end{abstract}

DESCRIPTORS: Nursing. Sociology. History of nursing. Social organization.

\section{CONSELHO REGIONAL DE ENFERMAGEM DE SANTA CATARINA (1975-1986): IMPORTÂNCIA PARA A PROFISSÃO}

RESUMO: Pesquisa histórico-social, de abordagem qualitativa, com objetivo de resgatar o processo de implantação do Conselho Regional de Enfermagem de Santa Catarina e caracterizar sua importância para a profissão. Apresenta sustentação teórica nas ideias de Eliot Freidson e na História Nova. Na metodologia, utiliza-se a história oral temática e a pesquisa documental, envolvendo oito enfermeiras(os) que participaram do órgão representativo no recorte temporal. Os preceitos da Análise de Conteúdo orientaram a análise de dados, os quais foram organizados segundo as gestões do Conselho Regional de Enfermagem de Santa Catarina de 1975 a 1986. Na implantação do Conselho, verificou-se frágil conhecimento da categoria acerca dos objetivos do órgão regulamentador e lentidão do processo fiscalizatório. Conclui-se que a importância da criação do Conselho para a profissão era entendida pelas lideranças e pouco pelo conjunto dos profissionais do Estado.

DESCRITORES: Enfermagem. Sociologia. História da enfermagem. Organização social.

\section{CONSEJO REGIONAL DE ENFERMERÍA DE SANTA CATARINA (1975-1986): IMPORTANCIA PARA LA PROFESIÓN}

RESUMEN: Investigación histórico-social con enfoque cualitativo realizada con el objetivo de rescatar el proceso de implantación del Consejo Regional de Enfermería (Conselho Regional de Enfermagem) de Santa Catarina y de caracterizar su importancia para la profesión. Se apoya teóricamente en las ideas de Eliot Freidson y en la Historia Nueva. Como metodología se utiliza la historia oral temática y la investigación documental con la participación de ocho enfermeras(os) que formaron parte del órgano representativo durante el corte temporal establecido. Os preceptos del Análisis de Contenido orientaron el análisis de los datos, que se organizaron según las gestiones del Consejo Regional de Enfermería de Santa Catarina desde 1975 hasta 1986. Durante la implantación del Consejo se puso de manifiesto el frágil conocimiento de la categoría acerca de los objetivos del órgano regulador y la lentitud del proceso de fiscalización. Se concluye que la importancia de la creación del Consejo para la profesión sí era comprendida por los líderes, pero poco por el conjunto de profesionales del estado.

DESCRIPTORES: Enfermería. Sociología. Historia de la enfermería. Organización social. 


\section{INTRODUCTION}

This study aimed to rescue the deployment process of the Regional Nursing Council of Santa Catarina in the first eleven years of its management (1975-1986) and characterize its importance for the profession. The Regional Nursing Council of Santa Catarina (Coren/SC) was installed in October 1975, during a context that demanded improvements in professional training for actions in the government healthcare programmes. ${ }^{1}$ The nursing leaderships in charge of the Brazilian Nursing Association (ABEn) had been struggling, during thirty years, to create a Professional Council, which was accomplished in the 1970s. In the debates on the importance of qualifying the practice and strengthening nursing as a health profession, the need for a regulatory and disciplinary organization for the professional practice had already been acknowledged.

This debate is consistent with the reflections on the Sociology of Professions, which considers profession as "an occupation that controls its own work and is organized by a special set of institutions, which are partially sustained by a particular experience of ideology and usability" 2:33 The profession is organized around activities and a proper theoretical body (expertise/esoteric skill) and guaranteed by credentials (education, regulatory standards) that qualify the work and provide professional autonomy. Any profession requires representative bodies, specific and formal education, knowledge and systematic practices and practice guided by ethical principles recognized by the State and society. Studies using a critical approach of the Sociology of Professions argue that nursing is a healthcare profession grounded on scientific findings, self-regulation and autonomy to perform by means of care practices and cooperative education to people, in a relation of interdependence with its partners and other health professionals. ${ }^{3-5}$

The description of the implementation history of Coren/SC, by analyzing it from the perspective of Sociology of Professions, contributes to the understanding of the structure of nursing as a healthcare profession.

\section{METHODOLOGICAL APPROACH}

Historical-social research with qualitative approach, based on the theoretical argument of the New History and the ideas of Eliot Lazarus Freidson, which are centered on the sociology of professions.
The historical period from 1975 to 1986 is marked in the constitution of the Federal Nursing Council (Cofen) and Regional Councils (Coren) by Ordinance number 3059, of March 5, 1975 and installed on April 23, 1975, and specifically the creation and deployment of Coren/SC. It establishes the limit landmark in 1986 by the approval of Law number 7.498, of June 25, 1986, which regulates the Professional Nursing Practice, regulated by Decree number 94.406 of June 8, 1987.

Eight nursing professionals of the State of Santa Catarina participated in this study, according to the following inclusion criteria: nursing professionals who comprised the organizational and administrative structure of Coren/SC in the period between 1975 and 1986; other professionals and people who worked for the creation and implementation of Coren/SC. The participants are identified by names, observing the authorization formalized in a document, as recommended in studies using oral sources in historical and social research. ${ }^{6-7}$

The Oral History method was used along with documentary research, from December 2011 to March 2013. Semi-structured interviews were performed with digital recording, in places, dates and times scheduled by the respondents. Subsequently, the interviews were transcribed and the material was presented to the interviewees for their validation. The documentary research covered primary sources, including Laws, Meeting Minutes and Terms of Tenure, which contributed to the historicity. For the treatment of the data, Bardin's content analysis ${ }^{8}$ was used, with the following stages: $1^{\text {st }}$ Stage: composed by exhaustive reading of the transcripts of the interviews and documental inventories with recursive studies on the collected material, $2^{\text {nd }}$ Stage: thematic cuts including meaning units were performed in the statements on the subjects. The documents and interviews were used as registration units, in which the use of data provided the coding. They were organized in tables comprising the complete discourse of each individual of the research and the units of meaning. $3^{\text {rd }}$ Stage: At this stage, the ideas and facts were classified and ranked. For the enunciation procedure, which is based on thematic categories, the grouping of codes was performed by significance. The thematic categorization was carried out after full composition and exhaustive reading: Coren/SC in the first four mandates, from 1975 to 1986.

The study received approval from the Institutional Review Board of the Universidade Federal 
de Santa Catarina, under Opinion number 2.329 FR 474453, of November 28, 2011.

\section{RESULTS AND DISCUSSION}

The implementation process of Coren/SC is historicized and analyzed based on the exposure of the meaning units into one category. ${ }^{8}$ These discussions evolved from the implementation process of the activities of this entity in the eleven years of its management. In this context, ideals were revealed and the dialogues with the features of the profession were registered.

\section{The Regional Nursing Council of Santa Catarina in the mandates from 1975 to 1986}

\section{Mandate 1975-1978}

After ABEn-SC organized the call and registration of the professionals in the State, it was allowed the vote on a single list for Coren/SC. Subsequently to this action and the presentation of the elected Board members, the first Ordinary Plenary Meeting (OPM) was held. During this meeting, the election of the board members and those elected by the professional category took place for the management period from 1975 to 1978. The meeting occurred after the Nursing Journey of Santa Catarina, on October 22 $2^{\text {nd }} 1975 .{ }^{9}$ During this occasion, nurse Rosita Saupe was nominated president (she currently signs as Rosita Alves da Silva Morgado), followed by the nomination of nurse Maria Alba Monguilhot da Luz as secretary and nursing assistant Helena Fernandes Xavier as treasurer. Solange Wink, Maria Alba Monguilhot da Luz and Giselda B. Burger, as deputy members, constituted the group in charge of the accountsmaking process of the representative body. In the subsequent meetings, the plenary council composed the ethics committee; approved the names of Elizabeta Lengert, João Flávio Vendrúsculo and Giselda B. Burger as counselors and the internal regulation of the Coren/SC, the hiring of Inesita Maria Cabral as an executive secretary, and Luzia Machado as desk clerk. These acts received approval from the technical consultant of Cofen. ${ }^{10-11}$ From that moment, the disciplinary and supervising feature of the nursing practice in Santa Catarina became official. The statements below show the findings mentioned.

We need to create conditions to bring professionals together and appoint an executive board to empha- size the new Council. Nurses and authorities were all gathered in Joinville (Lydia Ignes Rossi Bub).

In this way, Coren/SC started, and we were the counselors and we were in charge of choosing the President and it was in Joinville that this election occurred (Rosita Alves da Silva Morgado).

In the development circumstances of Coren/ $\mathrm{SC}$, the difficulties were centered on the adherence of the people, regarding their work relationships, power and status, which sharply emerged through the establishment of the agency. The expressiveness of the technical division of nursing work is noticed, with power and professional appreciation differences.

The commitment of the first management was focused on finding and encouraging professionals to sign up, as presented by the deponent:

our main concern was to enroll the professionals, then the inspection came afterwards, but our concern was to convince the nurses and everyone should be enrolled in the Council, subsequently the other professionals (Lucia Herta Rockembach).

The first administration of Coren/SC has committed to expanding the registry of professionals throughout the state. The nurses Flérida Goudel de Cardoso and Marlene Maria de Medeiros played an important role in disseminating and calling the professionals for registration and enrollment in the Coren/SC, through their professional positions in governmental institutions in the State, within the nursing scope. However, the category members had difficulty understanding the requirement of their registration in the Council.

In the approach of Sociology of Professions, entities play a key role in the structuring of a profession since financial resources are needed for the performance of their duties. ${ }^{12}$ The issues intrinsic to the Coren/SC regarding these resources began to be planned and resulted in a physical, material and financial organization of the entity. In the early months of the Council's activities, the ABEn/SC paid the expenses resulting from the activities inherent to the organ..$^{10}$ Such costs were later on transferred and paid by Cofen. In 1976, a head office rented for the functioning of the Coren/ SC was acquired with the support of Cofen. The own head office would only be acquired on July $5,1991 .^{13}$

Professional bodies are the life of the profession. So, we delimited the workload, according to the teaching workload, as most had exclusive dedication jobs. Both acting in ABEn and in Coren was part of the job. It was 
confusing because the University was the ABEn and the $A B E n$ was the University. Of course, in $A B E n$, there were others who were not from the University, but the leadership was very strong (Eloita Pereira Neves).

The ABEn was the idealization center and spurred the creation of the Cofen system and the Regional Councils. In Santa Catarina, the movement to achieve the Board took place in the ABEn$\mathrm{SC}$, and the profession's leaders circulated between the Association and the Federal University of Santa Catarina. In a sense, the understanding of the services' managements facilitated the participation of the professional entities in the activities.

During this management, there were discussions about inspection activities and, on October 29, 1976, Cofen Resolution number 30 was approved, which provided for the Inspection System. It is worth emphasizing that the fiscalization process took a while to be accomplished. It suggests, therefore, inefficiency in the effectiveness of the core purpose of Cofen.

It is the responsibility of the profession to define the quality standards of its activity and ensure the regulatory practice. ${ }^{12}$ The exercise of a profession requires skilled and trained staff, according to the normalization and standards recognized by the profession, scientific community and society.

The activities of Coren/SC during the implementation process were basically related to the conquest and orientation of the nursing staff in assuming the responsibility of the professional enrollment. In this professional activity, the amount of professionals reached 99 nurses, 125 nurses and 24 nursing assistants and 24 nursing technicians, totaling 248 nursing professionals. ${ }^{14}$ The Cofen records do not document the number of nursing attendants and midwives at that time.

On October $17^{\text {th }} 1978$, the election campaign for the second Management of Coren/SC took place, with only one list inscribed.

\section{Mandates 1978-1981, 1981-1984}

In the period from 1978 to 1981, Lydia Ignes Rossi assumed as president, Lucia Herta Rockembach as secretary and Ingrid Elsen as treasurer. The accounts-making commission was under the responsibility of Helena Fernandes Xavier, Cleuza Taranto and Maria de Lourdes de Souza. At that time, the agency was still part of the members of the socio-political nursing circle of the state, either due to the interest of the group in strengthening the local authority or political nature of the activity of Coren/SC, which required committed professionals. It possibly resounds as a commitment to set up the establishment of Coren/SC. The Plenary of Coren/SC planned actions for its internalization in the State, in order to guide practitioners about the activities of the Council, which were not restricted to the charging of laws and regulations.

We could not convince them that it was important. And perhaps we also erred by not answering clearly the objectives, because if we knew it clearly, we would easily go to a hospital and gather the assistants. Our concern was to conquer staff to enroll in the Council (Lúcia Herta Rockembach).

For the nursing assistants, their duties were always performed and they never needed to financially spend on fees to exercise their profession. The inclusion of practitioners remained difficult and the collaboration of the managements of facilities and health services was essential, since most of the nursing staff developed their activities in hospital institutions. In the sociological concept, these relationships are important, because they facilitate the normalization of the profession by the State, as acknowledgment. It is noted that boards, councils or professional associations do not hold the exclusive right to impose professional rules. However, they represent a formal and legal organizational structure in which the work is carried out. ${ }^{12}$ Consequently, resources are needed.

Therefore, in the first board of directors, the registration started. All registrations - the rate - went to the Federal Council, which distributed according to the needs and they had staff. For a certain period, everything was financially supported by COFEN, employees, rent, furniture, installation, and this all was financed by it (Lydia Ignes Rossi Bub).

The Cofen ensured financial resources, which provided the rental of the head offices, staffing, materials needed to provide for the local authority. ${ }^{15}$ Thus, it enabled the Regional Councils to maintain its head office and permitted the councilors' travels to the interior of the State to disclose the entity and conquer new affiliations. During this period, they completed the management with the sum of 499 professionals and, of these, 158 were nurses, 219 assistants and 122 nursing technicians.

In 1979, a special committee was organized, under the coordination of the nurse Maria Helena Bittencourt Westrupp, to study the discipline and professional inspection systems of nursing and its 
auxiliary occupations. Ingrid Elsen, Lucia Herta Rockembach, Helena Fernandes Xavier, Cleuza Taranto participated in this task. "The period from October 31, 1979 to October 30, 1980 was designed for the organization of elections for the future management of Coren/SC." 16:18 In the meantime, the project number $3.427 / 80$ regarding the Law of Professional Nursing Practice, under the authorship of deputy Mr. Gibson Vilson, was analyzed by the Justice Commission. "Coren/SC addressed letters to Deputies rapporteurs who were favorable to the approval of this norm for nursing". ${ }^{17: 45}$ Here, the influence of the State on the recognition of professions is observed. Any profession depends on negotiations with the State for establishing and maintaining ethical standards and reproduction of professional practices, supported by laws. ${ }^{18}$ The professional Council officially represents the profession and by means of negotiations with the State, it participates in the ideas to establish, maintain, expand and defend legal advantages. ${ }^{12}$

The internal movements of Coren/SC proceeded and the electoral process to compose the third mandate occurred in June 23, 1981, with a total enrollment of 938 voters and, among these, 298 were nurses, 640 technicians and nursing assistants. These data reveal a similarity between the number of nurses registered in Coren/SC and the number possibly existing in Santa Catarina in the early 1980s. ${ }^{17}$ These three years of performance of Coren/SC in the State were marked by the intensification of the establishment process of supervision activities. A selection was carried out in August 1983, in which the name of Verita Conceição Elias appears, a nurse from Porto Alegre, ${ }^{19}$ hired as the first auditor of Coren/SC, along with another candidate, whose name does not appear in the records and who remained only one month in the position. ${ }^{20}$ The process of inspection was triggered more effectively during this period, under the leadership of nurse Lidvina Horr.

Professor Lidvina was part of the second management. Then she was a secretary and started working on the supervision. We started a guiding rather than inquisitive supervision, it was actually a clarifying inspection (Lydia Ignes Rossi Bub).

Lidvina Horr was one of the toughest people we knew. She clearly knew laws, she got well prepared, and so the supervision began from there. A team was formed, and she led this team and worked a lot (Lúcia Herta Rockembach).

The nurse Lidvina Horr was crucial in the training and organization of the entire inspection system of Coren/SC. She was an important leadership in the State, a professional who gave support and remained committed to the activities of Coren/SC during many managements. She was recognized as the organization precursor of the inspection process of Coren/SC. At the end of this administration, data showed the registration of 188 nurses, 232 assistants and 164 nursing technicians, a set of 584 professionals.

It is also noteworthy that the cooperative work of the nursing agencies contributed to the recognition of the profession by professional and social government training institutions in the State.

There was rather a growth both in terms of recognition of the profession Council as it was beginning to be recognized, the nursing profession. There were two entities to struggle while nurses were working. So, the Council began to gain a certain degree of respect (Lydia Ignes Rossi Bub).

Parallel to the autarchy's expansion in the State, the nursing of Santa Catarina experienced a political circumstance within the profession, which reflected the different ideals between the leadership of ABEn at National level and profession leaderships of some Brazilian States. This conflict of ideals gave rise to the Participation Movement $(\mathrm{PM})$ in ABEn-SC. There was involvement of the Council in this regard, although the records are limited to information about the meetings among leaderships of ABEn-SC and Coren/SC, without details about the content of the discussions.

\section{Mandate 1984-1987}

Amidst this dynamic, it was high time for a new electoral process of the Professional Council. New elections took place on October 30, 1984, with two competing lists. No records were found on the competitor plaque in the minutes of Coren/ SC. The nurse Edison José Miranda was elected the first male president of Coren/SC, Christiane Riggemback Verissimo Ribeiro as secretary and Josel Machado Corrêa as treasurer. "The accountsmaking commission was instituted with the

\footnotetext{
* The end date 1987 corresponds to the period of the Council management, which is every three years. The study cut has 1986 as the end date and is part of the Mandate 1984-1987.
} 
election of Jorge Luiz Wolff, Oníbio Schaves and Chagas Silvia Barreto." 21:112

This was the first election of Coren/SC with participation of two competing lists, resulting from social movements of the country's democratization and debate within the scope of the profession and ABEn. Since 1980, ABEn/SC had been emphasizing the PM leadership. In 1984, the PM was extended to other sections of ABEn and had nursing professionals who worked in other political and social movements against the military regime. ${ }^{22}$ Even in the face of difficulties and aspects that put the novelty in doubt, the PM streamlined the approval of the Law of Professional Nursing Practice, with important requirements for the profession. ${ }^{23}$ Students and professional leaders joined in this battle. The ideas of the PM resulted in criticism of the Cofen System and Regional Councils and formation of opposition lists. In Santa Catarina, in the fourth mandate of Coren/SC, the opposition candidate who won the election identified himself with the PM.

I was much criticized, I heard when I was a candidate to the Council, 'How are they going to let a newly formed young man, barely out of diapers direct the entity'. Another thing that was very characteristic was the fact of being a man, and then it was another thing we faced, despite winning by belonging to an opposing list (Edison José Miranda).

It was an administration that stood out by the dialogue with educational and health institutions and professional associations, as well as the expansion of inspection. At this time, the Coren/ SC had Valda Borges, Elizabeth de Oliveira, Carmen Lucia da Silva Laurindo, Marcos A. S. da Silva as employees and Verita Conceição Elias as tax nurse. "The tax nurse requested clearance for administrative reasons. Consequently, there was the hiring of two tax nurses, Adalberto Zorzo and Airton Francisco." 24:14

There were professionals to work in the inspection, but there was the need to expand the workforce to the supervisory and disciplinary activities of Coren/SC. It is recorded that this management ended the mandate with 264 nurses, 246 and 145 nursing assistants and technicians, respectively. Cofen counted 655 nurses in this period..$^{14}$

This was a mandate of changes in the organizational processes and directions of Coren/ $\mathrm{SC}$, as it was the first board with different members compared to the previous mandates. They performed as opposition to what was set. They wanted a political and democratic opening within Coren/SC and struggled, at that time, along with the PM for democratization within ABEn, which influenced the new perspectives of Coren/SC. In the midst of socio-political movements, the category maintained the struggle for the approval of the Bill of Professional Nursing Practice, which had been running, during these 11 years of Coren/ SC, since the creation of the Cofen System and Regional Councils. Law number 7498/86 and Decree number $94.406 / 87$ showed positive conquests with regard to nursing planning, execution and evaluation of healthcare plans and programmes. ${ }^{25} \mathrm{It}$ is important to reflect, however, that issues relating to working conditions, such as presidential vetoes of the new law, restricted or eliminated advances that could lead to professional autonomy. ${ }^{26} \mathrm{ABEn} /$ SC and Coren/SC had confluent interests during this struggle, mainly regarding the changes in $A B E n$, which were required by $P M$, resulting from the role of the nursing leadership in the State of Santa Catarina.

The first board of directors of Cofen organized the Nursing Ethics and Deontology Codes and the Law of Professional Nursing Practice. ${ }^{27}$ Law number 7.498, of June 25, 1986, under regulations of Decree number 94.406 of June 8,1987 , remains as one of the nursing legal devices, along with the Ethics Code of the Nursing Professionals. These normalizations ensure the legal exercise of the profession to professionals, establishing the activities specific to the nurses, and including duties of the other professional members such as technicians and nursing assistants. The performance of Coren/SC in these early eleven years shows the difficulties for the category to adhere to the real purposes of the representative organization, but the cooperative action of ABEn/SC and Coren/SC contributed to the strengthening of the profession.

\section{FINAL CONSIDERATIONS}

This study shows that few people's action is the opportunity to awaken the consolidation of acts and purposes. However, any professional group has the responsibility to emphasize and ensure its professional identity based on professionalism. The recognition of the relevance and importance of a nursing regulatory body by health, education, governmental and social institutions in the state,was central to the consistency of Coren/ 
$\mathrm{SC}$ as the voice, along with ABEn/SC, of nursing as a profession in the South of Brazil. It was also amplified in the socio-political movements, especially the PM, which transformed the history of nursing across the country.

The professionalist society, in the opinion of the authors of this study, is concerned with the socio-professional collective, which respects and imposes, under the legend of professionalism, ideals and references of knowledge and self-regulation of autonomy, which are part of the profession. By means of discussions on the development context of Coren/SC, an expansion of the visibility and recognition of nursing in the State of Santa Catarina was observed. This is observed even in the face of the fragility in the understanding of the professional organization about the objectives of a disciplining and inspectioning body, which contributed to the length of the supervision process. Notably, the leaders understood the importance of a regulatory body. It was, however, limited or insignificant for all nursing professionals in the State, which modified the working relations within the profession and externally, regarding the interprofessional relations in healthcare.

It is understood that, from the diversity of interests among members of the same professional group, there are transformations and developments between the parties. No profession develops without organization of its members and without representative organizations that certify to society the need and the value of its activity. Most importantly, it has to attest to society the value of its work and respectability to the human.

\section{REFERENCES}

1. Kletemberg DF, Vieira M, Bertoncini JH, Padilha MI, Borenstein MS. O fascínio da ciência na área da saúde (1960-1990). In: Padilha MI, Borenstein MS, Santos I, organizadoras. Enfermagem história de uma profissão. São Caetano do Sul (SP): Difusão Editora; 2011. p. 295-334.

2. Freidson E. Renascimento do profissionalismo: teoria, profecia e política. Tradução: Celso Mauro Parcionik. São Paulo (SP): EDUSP; 1998.

3. Bellaguarda MLR. Nexos e circunstâncias na história do Conselho Regional de Enfermagem em Santa Catarina (1975-1986) [tese]. Florianópolis (SC): Universidade Federal de Santa Catarina, Programa de Pós-Graduação em Enfermagem; 2013.

4. Pires D. A enfermagem enquanto disciplina, profissão e trabalho. Rev Bras Enferm 2009 SetOut;62(5):739-44.
5. Bellaguarda MLR, Padilha MI, Pereira Neto AF, Pires D, Peres MAA. Reflexão sobre a legitimidade da autonomia da enfermagem no campo das profissões de saúde à luz das ideias de Eliot Freidson. Esc. Anna Nery 2013 Abr-Jun;17(2):369-74.

6. Padilha MICS, Ramos FRS, Borenstein MS, Martins CR. A responsabilidade do pesquisador ou sobre o que dizemos acerca da ética em pesquisa. Texto Contexto Enferm. 2005 Jan-Mar; 14(1):96-105.

7. Padilha MI. Pesquisando em saúde e enfermagem. Texto Contexto Enferm. 2008 Out-Dez; 17(4):623-4.

8. Bardin L. Análise de conteúdo. Lisboa (PT): Edições 70; 2010.

9. Conselho Regional de Enfermagem (SC). Ata da $21^{\mathrm{a}}$ reunião ordinária plenário de 22 de outubro de 1975. Florianópolis (SC): Coren; 1975a.

10. Conselho Regional de Enfermagem (SC). Ata da $2^{\mathrm{a}}$ reunião ordinária plenário de 12 de novembro de 1975. Florianópolis (SC): Coren; $1975 b$.

11. Conselho Regional de Enfermagem (SC). Ata da $3^{\mathrm{a}}$ reunião ordinária plenário de 12 de dezembro de 1975. Florianópolis (SC): Coren; 1975c.

12. Freidson E. Profissão médica: um estudo de sociologia do conhecimento aplicado. São Paulo: UNESP; Porto Alegre (RS): Sindicato dos Médicos; 2009.

13. Conselho Regional de Enfermagem (SC). Escritura pública de compra e venda, 5 de julho de 1991, livro 226, folha 196. Vanda de Souza Salles 4 Tabelião de notas e 4 ofício de protestos. 1 traslado. Florianópolis (SC): Coren; 1991.

14. Conselho Federal de Enfermagem (BR). Tabela de inscritos no Coren/SC. Brasília (DF): Cofen; 2013.

15. Garcia CLLM, Moreira AM. A Associação Brasileira de Enfermagem e a criação do Conselho profissional no Brasil. Rev Pesq Cuid Fundam [online]. 2009 [acesso 2013 Fev 12]; 1(1):97-110. Disponível em: http://www.seer.unirio.br/index.php/ cuidadofundamental/article/view/314/280

16. Conselho Regional de Enfermagem (SC). Ata da $52^{\mathrm{a}}$ reunião ordinária plenário de 13 de setembro de1979. Florianópolis (SC): Coren; 1979.

17. Conselho Regional de Enfermagem (SC). Ata da $1^{\mathrm{a}}$ reunião extraordinária plenário de 23 de junho de 1981. Florianópolis (SC): Coren; 1981.

18. Faulconbridge JR, Muzio D. Professions in a globalizing world: towards a transnational sociology of the professions. Internat Sociol. 2011; 27(1):136-52

19. Costa E. Hospital Colônia Sant'Ana: o saber/poder dos enfermeiros e as transformações históricas (1971-1981) [tese]. Florianópolis (SC): Universidade Federal de Santa Catarina, Programa de PósGraduação em Enfermagem; 2010.

20. Conselho Regional de Enfermagem (SC). Ata da $1^{\mathrm{a}}$ reunião ordinária plenário de 12 de agosto de 1983. Florianópolis (SC): Coren; 1983. 
21. Conselho Regional de Enfermagem (SC). Ata da $116^{a}$ reunião ordinária plenário do Termo de posse n. 22 de 30 de outubro de 1984. Florianópolis (SC): Coren; 1984

22. Germano RM. Organização da Enfermagem Brasileira. Enferm Foco. 2010; 1(1):14-7.

23. Lorenzetti J, Pires DP, Spricigo J, Schoeller SD. Unidade de ação: um desafio para a enfermagem brasileira. Enferm Foco. 2012; 3(3):152-4.

24. Conselho Regional de Enfermagem (SC). Ata da $123^{\circ}$ reunião ordinária plenário de dois de maio de 1985. Florianópolis (SC): Coren; 1985.
25. Pires D, Lorenzetti J, Albuquerque GL. O movimento participação na associação brasileira de Enfermagem (ABEn): história e desafios na representação profissional. In: Padilha MI, Borenstein MS, Santos I, organizadoras. Enfermagem história de uma profissão. São Caetano do Sul (SP): Difusão Editora; 2011.

26. Backes VMS. Estilos de pensamento e práxis na Enfermagem: a contribuição do estágio préprofissional. Ijuí (RS): UNIJUÍ; 2000.

27. Oguisso T, Schmidt MJ, Freitas GF. Fundamentos teóricos e jurídicos da profissão de enfermagem. Enferm Foco. 2010; 1(1):9-13. 